\title{
Response of carbon fluxes to water relations in a savanna ecosystem in South Africa
}

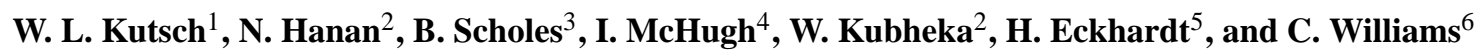 \\ ${ }^{1}$ Max-Planck-Institute for Biogeochemistry, P.O. Box 1001 64, 07701 Jena, Germany \\ ${ }^{2}$ Natural Resource Ecology Laboratory, Colorado State University, Fort Collins, USA \\ ${ }^{3}$ Council for Scientific and Industrial Research (CSIR), Natural Resources and the Environment, P.O. Box 395, \\ 0001 Pretoria, South Africa \\ ${ }^{4}$ School of Geography and Environmental Science, Monash University, Clayton, Australia \\ ${ }^{5}$ South African National Parks (SANParks), Scientific Services, Skukuza, South Africa \\ ${ }^{6}$ Graduate School of Geography, Clark University Worcester, MA, USA
}

Received: 17 March 2008 - Published in Biogeosciences Discuss.: 27 May 2008

Revised: 23 September 2008 - Accepted: 6 October 2008 - Published: 23 December 2008

\begin{abstract}
The principal mechanisms that connect carbon fluxes with water relations in savanna ecosystems were studied by using eddy covariance method in a savanna ecosystem at Kruger National Park, South Africa. Since the annual drought and rewetting cycle is a major factor influencing the function of savanna ecosystems, this work focused on the close inter-connection between water relations and carbon fluxes. Data from a nine-month measuring campaign lasting from the early wet season to the late dry season were used.

Total ecosystem respiration showed highest values at the onset of the growing season, a slightly lower plateau during the main part of the growing season and a continuous decrease during the transition towards the dry season.

The regulation of canopy conductance was changed in two ways: changes due to phenology during the course of the growing season and short-term acclimation to soil water conditions.

The most constant parameter was water use efficiency that was influenced by VPD during the day but the VPD response curve of water usage did change only slightly during the course of the growing season and decreased by about $30 \%$ during the transition from wet to dry season.

The regulation of canopy conductance and photosynthetic capacity were closely related. This observation meets recent leaf-level findings that stomatal closure triggers downregulation of Rubisco during drought. Our results may show the effects of these processes on the ecosystem scale.
\end{abstract}

Correspondence to: W. L. Kutsch (wkutsch@bgc-jena.mpg.de)

\section{Introduction}

Savannas are defined as tropical and sub-tropical vegetation types where woody plants and grasses co-dominate. They are characterized by a seasonal change of water availability with distinct rainy and dry seasons. Decades of research have identified not only water, but also nutrients, herbivory, and fire as major drivers of savanna vegetation dynamics (Walter, 1939, 1971; Scholes and Walker, 1993; Scholes and Archer, 1997; Sankaran et al., 2004; 2005; Beerling and Osborne, 2006).

Despite large land surface coverage ( $20 \%$ of the global land surface and $40 \%$ of the African surface), important biodiversity ( $~ 8000$ of 13000 African plant species are savanna endemic, White, 1980) and substantial land use change in savannas, there have been relatively few projects focusing on the patterns and processes controlling savanna carbon and water vapour exchange (Levy, 1995; Verhoef et al., 1996; Lloyd et al., 1997; Hanan et al., 1998; Scanlon and Albertson, 2004; Veenendaal et al., 2004; Williams and Albertson, 2004, 2005, for African savannas; Meir et al., 1996; Miranda et al., 1997; Meinzer et al., 1999; da Rocha et al., 2002; Santos et al. 2003, for South American savannas; Hutley et al., 2000, 2001, 2005; Chen et al., 2002, 2003; Beringer et al. 2003, for Australian savannas; Baldocchi et al., 2004 for temperate Mediterranean savannas in California).

Increasing our understanding of the physical and physiological controls on savanna functioning using eddy covariance measurements is of great importance both for fundamental ecological understanding as well as for improved management and conservation of these important ecosystems. Such measurements will, furthermore provide basic data for refining models of ecosystem carbon dynamics and facilitate improved understanding of the role of tropical

Published by Copernicus Publications on behalf of the European Geosciences Union. 
savannas in global carbon cycles, as well as informing policies related to the role of African countries in Kyoto Protocol.

One of the few infrastructures enabling the study carbon and water relations of African savannas is the flux tower in the Kruger National Park, installed between Skukuza and Pretoriuskop in 2000. In this study we investigate principal mechanisms that connect carbon fluxes with water relations in savanna ecosystems and differences between the two savanna types. Since the annual drought and rewetting cycle is a major factor influencing the function of savanna ecosystems, this work is focused on two questions concerning water relations: (1) How do water availability and seasonality drive ecosystem respiration?; and (2) how does the close interconnection between canopy conductance and photosynthesis, influence the carbon uptake by the vegetation during times of different water availability?

Ecosystems respiration as measured by the eddy covariance technique is the sum of soil, plant, and animal respiration. In biomes with a pronounced rainfall seasonality and/or water limitation, the temperature response may be secondary to the response to water availability.

Ecosystem photosynthesis is likewise controlled by a complex interaction of processes that connect carbon fluxes and water relations. The control of $\mathrm{CO}_{2}$ and water vapour exchange between ecosystems and the atmosphere by the stomatal aperture of plant leaves is the hinge between the two cycles - particularly notable in arid and semi-arid biomes.

However, the same stomata do not always react to the short-term (diurnal) variations of VPD in the same way. Leaf stomatal sensitivity and maximum conductance can be modified within periods of several days to few weeks by phenology and by acclimation to factors such as soil water status (Halldin et al., 1984). Kutsch et al. (2001a) assessed the influence of this mid-term stomatal acclimation on ecosystem fluxes by calculating canopy water and carbon balances for several years under different climates. In this context it is important to consider that canopy photosynthetic capacity $\left(\mathrm{F}_{\mathrm{P}, \text { sat }}\right)$ is strongly correlated to maximum surface conductance $\left(\mathrm{G}_{\mathrm{s}, \mathrm{sat}}\right.$; Schulze et al. (1994)).

By combining the regulation of respiration on one hand and stomatal conductance and photosynthesis on the other we provide a principle analysis of the temporal dynamics in the regulation of savanna carbon fluxes by water relations. We used data from a nine months period between January and September 2003 for this study. For annual balances of this site and improved gap-filling procedures we refer to Archibald et al. (2008).

\section{Methods}

\subsection{Research site}

The Skukuza flux tower was established in early 2000 to study the carbon, water and energy dynamics of semi-arid
African savannas (Scholes and Archer, 1997). The site was part of the SAFARI 2000 experiment to understand the interactions between the atmosphere and the land surface in southern Africa (Otter et al., 2002; Scholes et al., 2001; Shugart et al., 2004). The location of the tower is about $13 \mathrm{~km}$ WS W of Skukuza in the N'waswitshaka catchment, an ephemeral tributary of the Sabie River. The altitude of the site is $365 \mathrm{~m}$ a.s.l. The underlying parent material is Archaean granite and gneiss. The landscape shows a typical undulating form with drainage lines about $3 \mathrm{~km}$ apart and ridge tops about $40 \mathrm{~m}$ above valley floors. This leads to a catenal pattern of soils and vegetation, with nutrient-poor Combretum savannas on the crests, and nutrient-enriched Acacia savannas on the lower parts of the slope.The flux tower is located at the boundary of the two plant communities. When the wind blows from the SE $\left(105^{\circ}-196^{\circ}\right)$, a fine-leaf Acacia savanna is sampled, and when it blows from the $\mathrm{N}\left(270^{\circ}-\right.$ $76^{\circ}$ ), a broad-leaf Combretum savanna is sampled. Sectoral analyses of eddy covariance measurements have been conducted successfully in previous studies (e.g. Kutsch et al., 2005).

Detailed soil and vegetation analyses of the two types are given in Scholes et al. (2001). They show that the soil in the Acacia savanna contains more clay, more nutrients such a nitrogen and phosphorous and also a higher cation exchange capacity than in the Combretum savanna. Volumetric field capacity $\left(\mathrm{WC}_{\mathrm{FC}}\right)$ is about 0.12 in the Combretum- and 0.2 in the Acacia-savanna. Volumetric water content at $-1500 \mathrm{kPa}$ ("wilting point", $\mathrm{WC}_{\mathrm{WP}}$ ) was 0.06 and 0.1 , respectively. Relative plant available water (RPAW) was calculated from the actual volumetric water content for the layers $0-10 \mathrm{~cm}$ and $0-30 \mathrm{~cm}$ by

$\mathrm{RPAW}=\frac{\left(\mathrm{WC}_{\mathrm{akt}}-\mathrm{WC}_{\mathrm{WP}}\right)}{\left(\mathrm{WC}_{\mathrm{FC}}-\mathrm{WC}_{\mathrm{WP}}\right)} \cdot 100$

Rainfall at the site averages $547.1 \mathrm{~mm}$ but with significant interannual variability. The first precipitation events of the rainy season generally occur in late September or October, with last rains in April or early May. However, much of the interannual variability in total precipitation arises with variation in the dates of first and last rains. Figure 1 shows the long-term monthly means of minimum and maximum temperature and the mean precipitation at Skukuza (data from 1960-1999, after Scholes et al. (2001)). Precipitation is shown as cumulative curve. In order to show a complete growing season the data are shown from August to July. Most of the annual rainfall occurs during the summer (October to April). In the lower part of Fig. 1 the monthly precipitation of the growing season 2002/2003 is compared to the long-term mean. The 2002/2003 growing season was very dry. Only half of the long-term amount of rain fell $(276 \mathrm{~mm})$.

The vegetation of the study site is open woodland with approximately $30 \%$ tree canopy cover in both Acacia and Combretum savanna types (Scholes et al., 2001). Leaf area index of the trees in both savanna types is similar, increasing to an 


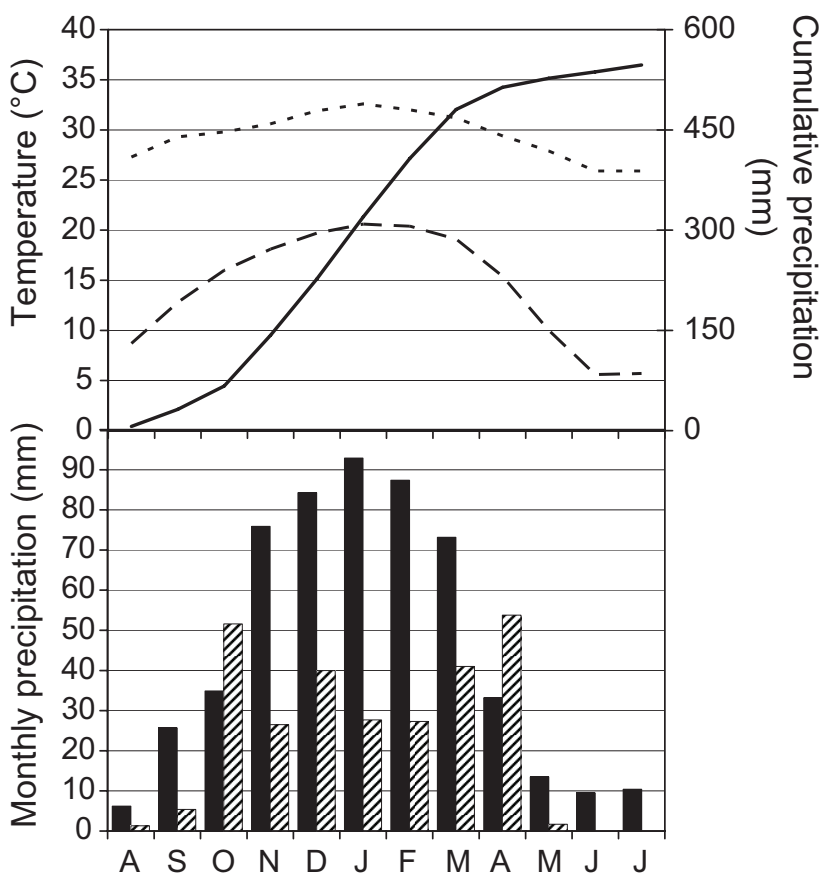

- Long- term mean 2002/2003

Fig. 1. Long-term monthly means of minimum and maximum temperature (dotted lines) and the mean precipitation (solid line) at Skukuza (data from 1960-1999, after Scholes et al. 2001). Precipitation is shown as cumulative curve. In order to show a complete growing season the data are printed from August to July. In the lower part the monthly precipitation of the growing season 2002/2003 (hatched bars) is compared to the long-term mean (black bars).

area average of approximately 1.0 (i.e. within canopy LAI 3.0) three or four weeks after the beginning of the rainy season and then remaining at that level until several weeks after the last rainfall. Thereafter, the trees in the Combretum savanna dropped their leaves, whereas the Acacia species remained leafy during the dry season. Herbaceous layer productivity and LAI is more dynamic with inter-annual variability in total rainfall, with average LAI of the herbaceous layer similar to the tree layer (i.e. 1.0), but in this case spread out more or less evenly across the landscape rather than being confined within the tree canopies.

\subsection{Eddy covariance system}

Ecosystem-level fluxes of water, heat and carbon dioxide were made using a closed-path eddy covariance system mounted at $16 \mathrm{~m}$. This consisted of a 3-dimensional sonic anemometer (Gill Wind Master Pro, Gill Instruments, Lymington, UK) to measure fluctuations in horizontal and vertical wind speeds $\left(\mathrm{m} \mathrm{s}^{-1}\right)$ and temperature $(\mathrm{K})$, and a gas analyzer (LiCor 6262, LiCor, Lincoln, Nebraska, USA) to measure carbon dioxide ( $\left.\mu \mathrm{mol} \mathrm{mol}{ }^{-1}\right)$ and water vapour $\left(\mathrm{mmol} \mathrm{mol}^{-1}\right)$ concentrations. The gas samples were drawn at $61 \mathrm{~min}^{-1}$ through a $6 \mathrm{~m}$ teflon-coated tube to the gas analyzer enclosed in a weather-proof box. The sonic anemometer and gas analyser measurements were recorded at $10 \mathrm{~Hz}$.

\subsection{Supplemental measurements}

Additional weather measurements on the main tower included measurements of incident and reflected shortwave radiation $\left(300-1100 \mathrm{~nm}, \mathrm{~W} \mathrm{~m}^{-2}, \mathrm{CM} 14\right.$, Kipp and Zonen, Delft, The Netherlands), incident and reflected near-infrared (CM14 600-1100 nm, W m ${ }^{-2}$, Kipp and Zonen, Delft, The Netherlands) and incoming and emitted longwave radiation (CG2, $>3.0 \mathrm{~nm}, \mathrm{~W} \mathrm{~m}^{-2}$, Kipp and Zonen, Delft, The Netherlands). Radiation measurements were made at $20 \mathrm{~s}$ intervals and then recorded in the data-logger as $30 \mathrm{~min}$ averages. Precipitation events were recorded with a tippingbucket raingauge (Texas Instruments TE525, mm) totalled for each $30 \mathrm{~min}$ period.

In addition to the meteorological and flux measurements on the main tower, we deployed supplemental microclimate stations in the adjacent Acacia and Combretum savannas to measure air temperature, air humidity, soil temperature and volumetric soil moisture. In each savanna we deployed TDR probes (Campbell Scientific CS615, $\mathrm{cm}^{3}$ water $\mathrm{cm}^{-3}$ soil) and temperature probes (Campbell Scientific $108,{ }^{\circ} \mathrm{C}$ ) in profiles with 4 or 5 measurement depths from near the soil surface to just above bedrock.

\subsection{Data treatment}

Post-processing of the raw high frequency $(10 \mathrm{~Hz})$ data to obtain fluxes representative of thirty minute periods involved the standard spike filtering, planar rotation of velocities, lag correction for $\mathrm{CO}_{2}$ and water vapour concentrations, and calculation of mass fluxes using conventional equations (Moncrieff et al., 1997; Aubinet et al., 2000).

Carbon dioxide flux $\left(F_{\mathrm{CO}_{2}}\right)$ was also corrected to include the canopy storage flux using the simple approach of assuming that the $\mathrm{CO}_{2}$ is uniformly distributed within the air column between the soil surface and the inlet of the tube:

$F_{\mathrm{CO}_{2}}^{\prime}=F_{\mathrm{CO}_{2}}+\Delta_{\mathrm{CO}_{2}} \cdot \frac{h \cdot 1000}{\eta \cdot t}$

where $F_{\mathrm{CO}_{2}}^{\prime}$ is the corrected flux $\left(\mu \mathrm{mol} \mathrm{CO} \mathrm{CO}^{-2} \mathrm{~s}^{-1}\right), F_{\mathrm{CO}_{2}}$ is the flux measured by the eddy covariance system ( $\mu \mathrm{mol}$ $\left.\mathrm{CO}_{2} \mathrm{~m}^{-2} \mathrm{~s}^{-1}\right), \Delta_{\mathrm{CO}_{2}}$ is the difference in $\mathrm{CO}_{2}$ concentration between $t^{0}$ and $t^{-1}$ (ppm), $h$ is the height of the air column $(16 \mathrm{~m}), \eta$ is molar volume of an ideal gas $\left(22.41 \mathrm{~mol}^{-1}\right)$, the factor 1000 converts 1 into $\mathrm{m}^{3}$, and $t$ is the time step of $1800 \mathrm{~s}$.

After calculation of the fluxes the eddy-covariance data were combined with and fitted against microclimate data. Nighttime carbon dioxide flux $\left(F_{n}\right)$, a surrogate for ecosystem respiration $\left(F_{R}\right)$, was regressed against soil temperature at $7 \mathrm{~cm}$ depth $\left(T_{S}\right)$ and soil moisture (RPAW, Eq. (1). 
Only data with a coincident friction velocity $(u *)$ greater than $0.25 \mathrm{~m} \mathrm{~s}^{-1}$ were used for this analysis.

The data set was fitted to the ecosystem respiration model described by Reichstein et al. (2002). This model provides response curves for soil moisture and temperature, and changes the $Q_{10}$-value of the temperature response curve with changing soil moisture as observed in this study:

$F_{R}=F_{R, \text { ref }} \cdot f\left(T_{\text {soil }}\right.$, RSWC $) \cdot g($ RSWC $)$

$f\left(T_{\mathrm{soil}}, \mathrm{RSWC}\right)=e^{E_{0}(\mathrm{RSWC}) \cdot\left(\frac{1}{T_{\mathrm{ref}}-T_{0}}-\frac{1}{T_{\mathrm{soil}}-T_{0}}\right)}$

$\left.g(\mathrm{RSWC})=\frac{\mathrm{RSWC}-\mathrm{RSWC}_{0}}{\left(\mathrm{RSWC}_{1 / 2}-\mathrm{RSWC}_{0}\right.}\right)+\left(\mathrm{RSWC}-\mathrm{RSWC}_{0}\right)$

where $E_{0}$ was not fixed but a linear function of relative water content (RSWC) allowing for a RSWC effect on temperature sensitivity. RWSC used as by Reichstein et al. (2002) was derived from the RPAW for the $0-10 \mathrm{~cm}$ layer by:

$\mathrm{RWSC}=\frac{\mathrm{RPAW}}{100}$

The modelled daytime ecosystem respiration $\left(F_{R}\right)$ was then used to calculate canopy assimilation $\left(F_{P}\right)$ from the daytime fluxes:

$F_{P}=F_{\mathrm{CO}_{2}}^{\prime}-F_{R}$

Canopy assimilation was then fitted against global radiation measured above the canopy by means of a tangens hyperbolicus ( $\tan h$ ) function (von Stamm, 1994):

$F_{P}=F_{P, \text { sat }} \cdot \tan h\left(\frac{k \cdot I}{F_{P, \mathrm{sat}}}\right)$

where $k$ is an empirical coefficient describing the initial slope of the light response curve and $I$ is the incoming short-wave radiation $\left(\mathrm{W} \mathrm{m}^{-2}\right)$.

Surface conductance, $G_{S}$, defined as the surface conductance to water vapour transfer at a canopy scale, was calculated from the eddy flux data as described by Jensen and Hummelshøj (1995) and Herbst et al. (2002). First, the total resistance, $r_{s}$, of the system was calculated as the quotient of vapour pressure deficit, VPD, of the air above the forest and water vapour flux, $E$. Analogously, the resistance owing to turbulent transport in the atmosphere, $r_{a}$, (assumed to be equal for momentum and water vapour) was determined as the quotient of mean horizontal windspeed, $u$, and the square of the friction velocity, $u *^{2}$. The resistance through the viscous sublayers on the individual leaves, $r_{b}$, was estimated as a function of the kinematic viscosity of the air, the molecular diffusivity of water vapour, the size of the leaves, the leaf area index, and the friction velocity (Jensen and Hummelshøj, 1995). Finally, surface conductance was calculated as the reciprocal of the residual resistance (Eq. 9):

$G_{S}=\left(\frac{\mathrm{VPD}}{E}-\frac{u}{u *^{2}}-r_{b}\right)$

If VPD is given in $\mathrm{g} \mathrm{m}^{-3}, E$ in $\mathrm{g} \mathrm{m}^{-2}, u$ and $u *$ in $\mathrm{m} \mathrm{s}^{-1}$, and $r_{b}$ in s m${ }^{-1}, G_{S}$ is obtained in $\mathrm{m} \mathrm{s}^{-1}$. To convert $G_{S}$ from $\mathrm{m} \mathrm{s}^{-1}$ into the common plant physiological unit of $\mathrm{mmol} \mathrm{m} \mathrm{m}^{-2} \mathrm{~s}^{-1}$, a multiplication factor has to be applied which is roughly 40000 .

In order to obtain an indication of the sensitivity of the regulation of canopy conductance to ambient humidity, $G_{S}$ was plotted against the actual water vapour pressure deficit of the air (VPD) for distinct periods of between two and four weeks with different levels of soil moisture. Each data set was fitted separately to the following equation:

$G_{S}=\frac{G_{S, \max }}{c \cdot \mathrm{VPD}^{2}}$

where $G_{S, \max }$ is a theoretical maximum conductance that occurs when VPD (mbar) is zero (set constantly to $2000 \mathrm{mmol} \mathrm{m}^{-2} \mathrm{~s}^{-1}$ in that study), and $c$ is an empirical coefficient that provides a measure of the sensitivity of the regulation of $G_{S}$. Envelope functions covering $90 \%$ of the data were fitted to the data by quantile regression (Cade and Noon, 2003). The seasonal course of the coefficient $c$ in Eq. (10) reveals how the canopy acclimates to changing conditions. This function is simpler and more empirical than the "Ball/Berry-Function" (Ball et al., 1987) that is commonly used but $c$ is defining the shape of the response curve in the same way and reveals the same seasonal pattern as the coefficient $D_{0}$ in the Ball/Berry approach does. We chose the more empirical function to avoid deriving physiological parameters top-down which is inappropriate for a physiologically heterogeneous system like a savanna.

\section{Results}

\subsection{Climate and flux overview}

Since 2002/2003 was a dry year, periods with low rainfall during the wet season resulted in periods of low soil moisture even during the typical vegetation growth period (Fig. 2a, Table 1). The dry periods can also be seen in decreases during the annual course in the $f_{\text {APAR }}$ (Fig. 2a). The net ecosystem exchange (Fig. 2b) and its components (canopy photosynthesis, $F_{P}$, Fig. 2c, and ecosystem respiration $F_{R}$, Fig. 2d) were strongly influenced by the soil moisture dynamics. Therefore, the observational data during the growing season were divided in the following sub-sets for further eco(system)physiological analyses. 


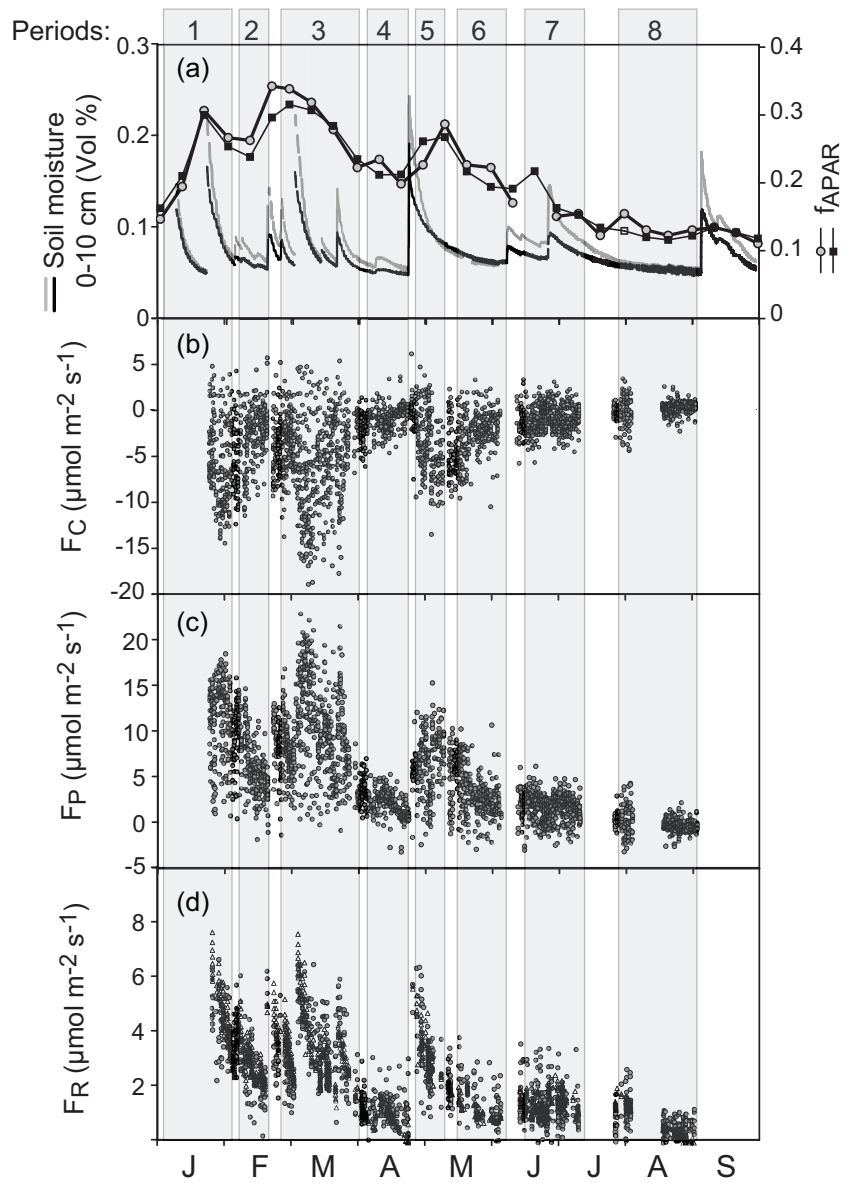

Fig. 2. Seasonal courses of volumetric soil water content for the layers $0-10 \mathrm{~cm}$ (a) in the Acacia savanna (grey line) and the Combretum savanna (black line) and of $f_{\text {APAR }}$ of two Modis grid cells around the tower (a), of net ecosystem exchange (NEE, (b), canopy photosynthesis $\left(F_{P},(\mathbf{c})\right.$ and total ecosystem respiration $\left(F_{R},(\mathbf{d})\right.$. The periods defined in Table 1 are marked in the Fig.

\subsection{Sectoral analysis and differences between savanna sites}

For a sectoral analysis data were sorted according to wind direction in order to examine differences between the two savanna types. Data from the sector between $105^{\circ}-196^{\circ}$ were taken for the fine-leaf Acacia savanna, from the sector between $270^{\circ}-76^{\circ}$ for the broad-leaf Combretum savanna. Data from other wind directions were discarded. There were no significant differences between the savanna types in terms of fluxes. As an example, Fig, $3 \mathrm{a}$ and $\mathrm{b}$ show light response curves of net ecosystem exchange $\left(F_{C}\right)$ and of canopy photosynthesis $\left(F_{P}\right)$ for the two sectors during the peak of the growing season (Period 3 as defined in Table 1, other periods showed the same picture). Consequently, data were pooled again for further analysis. The following paragraphs will show a principle analysis of carbon flux responses to water relations in a savanna ecosystem without considering possible small differences between the sub-types.
Table 1. Sub-sets for data evaluation in 2003 .

\begin{tabular}{clll}
\hline Dataset No. & Period & Characterization & Mean RPAW 0-10 \\
\hline 1 & 25 Jan-8 Feb & $\begin{array}{l}\text { Wet soil, } \\
\text { early wet season } \\
\text { Dry soil, } \\
\text { early wet season }\end{array}$ & 30.6 \\
3 & 10-20 Feb & 23 Feb-29 Mar soil, \\
mid wet season & 16.1 \\
4 & 1-25 Apr & $\begin{array}{l}\text { Dry soil, } \\
\text { mid wet season }\end{array}$ & 28.2 \\
5 & 27 Apr-11 May & $\begin{array}{l}\text { Wet soil, } \\
\text { transition period } \\
\text { Dry soil, } \\
\text { transition period }\end{array}$ & 11.6 \\
7 & 14 May-5 Jun & 39.1 \\
8 & 14 Jun-12 Jul & $\begin{array}{l}\text { Wet soil, } \\
\text { dry season } \\
\text { Dry soil, } \\
\text { dry season }\end{array}$ & 12.7 \\
\hline
\end{tabular}

(1) Averages were build on the basis of only those datasets that contained full information (climate and EC) after quality control and filtering. They might slightly differ from the "real" averages.

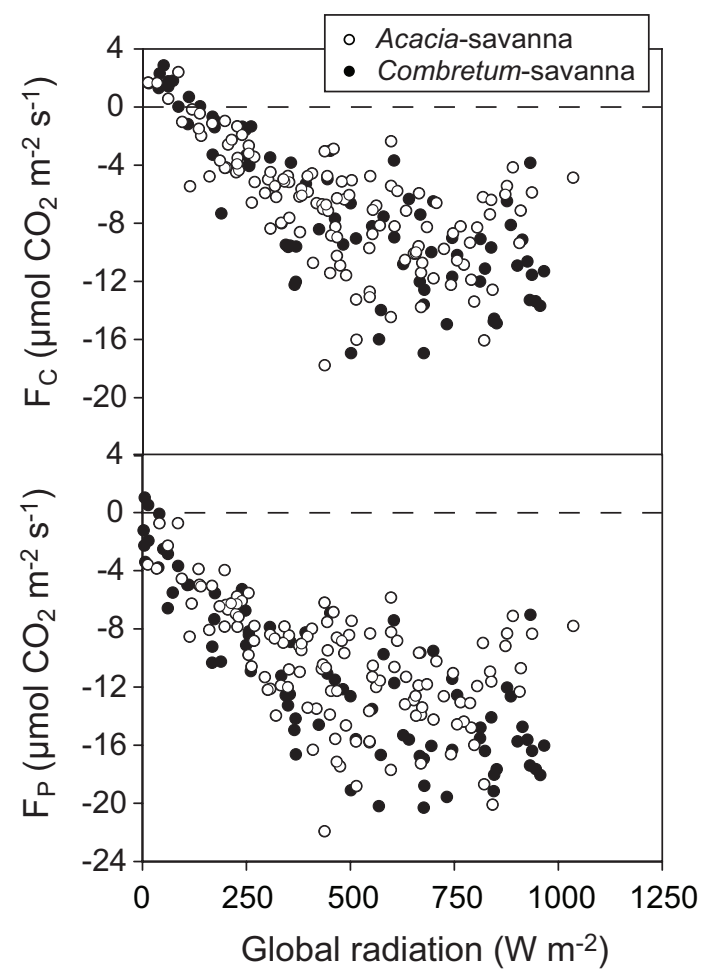

Fig. 3. Light response curves of net ecosystem exchange $\left(F_{C}\right.$, upper graph) and canopy photosynthesis $\left(F_{P}\right.$, lower graph) measured during the peak of the growing season (Period 3 in March 2003). The open symbols show data from the Acacia-site, the filled symbols from the Combretum-site. 


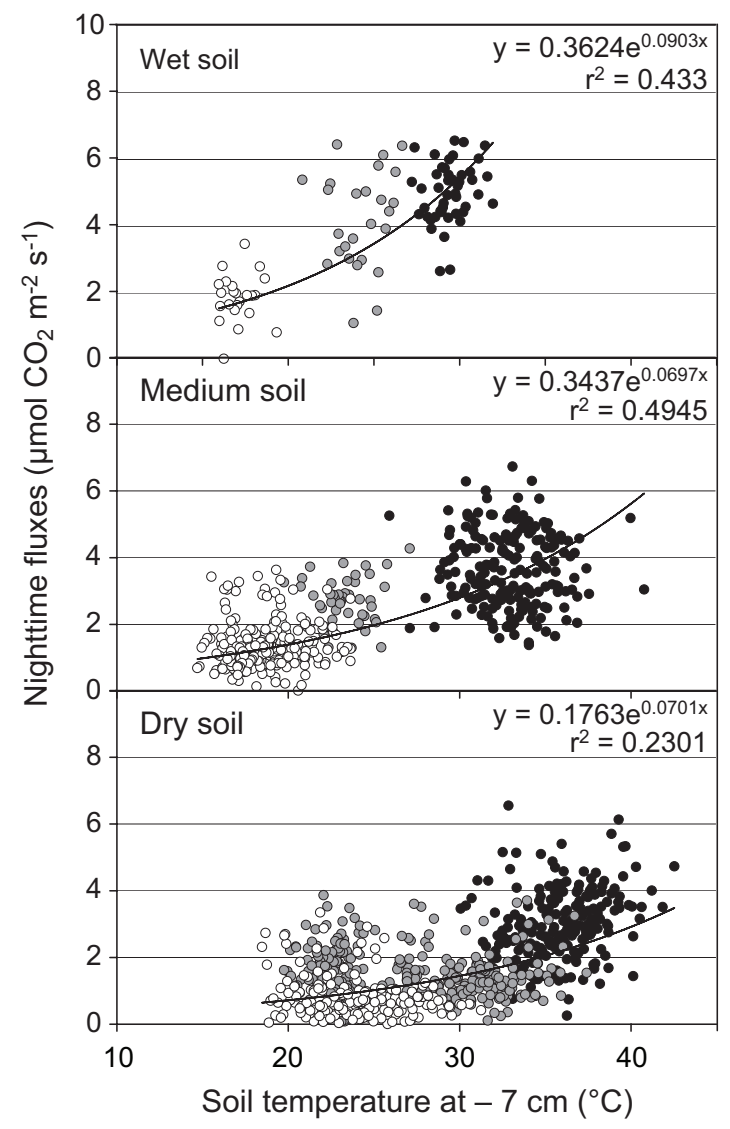

Fig. 4. Temperature response curves of nighttime respiration for different intervals of soil moisture. Filled cycles symbolize data from the main growing season (January-March 2003), grey cycles from the transition time (April-May 2003) and open symbols from the dry period (June-September 2003). The values of the exponential fits and the regression coefficient are related to the whole datasets comprising data from all seasons.

\subsection{Night time respiration}

In a first approach, the night time data sets identified for the analysis of the nocturnal fluxes after $u *$ filtering (1247 records) were divided into three classes of relative soil water content. Within each of these classes an exponential temperature response curves was generated. The analysis revealed a clear exponential increase of ecosystem respiration with increasing temperature and also a positive influence of soil moisture (Fig. 4). In addition, the data showed that the temperature response was modified by soil moisture: at low soil moisture the $Q_{10}$-value of the temperature function was reduced in comparison to high soil moisture. Thus, the data set was fitted to the ecosystem respiration described by Reichstein et al. (2002) which provides response curves for soil moisture and temperature, and changes the $Q_{10}$-value of the temperature response curve with changing soil moisture as observed in this study.

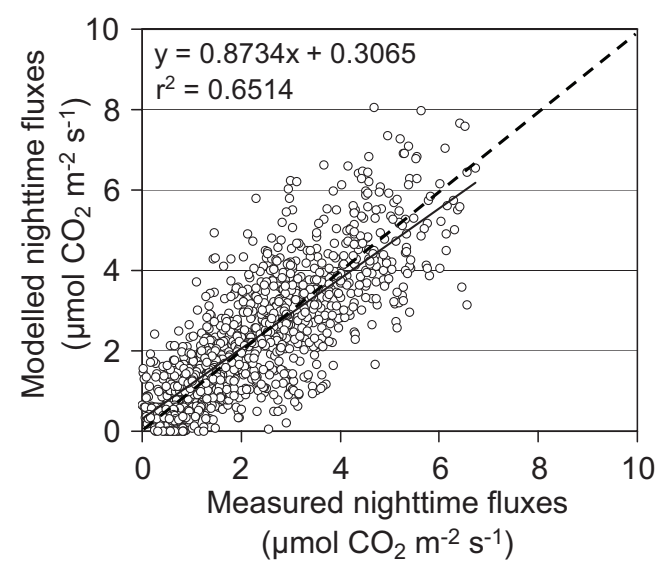

Fig. 5. Comparison between measured and modelled data of nighttime respiration. Based on complete data set (January-September 2003). The solid line represents the regression (regression values written at the top), the 1:1 line is dashed.

Figure 5 shows the modelled versus measured rates. Results indicate that this model approach explains much of the variation in flux rates and confirm the hypothesis about an indirect effect of water availability on ecosystem respiration via changes of temperature sensitivity $\left(Q_{10}\right)$ for which Reichstein et al. (2002) developed their model expression.

3.4 Seasonal characteristics of canopy conductance and photosynthesis

VPD response curves of $G_{S}$ were plotted for each of the defined periods as envelope curves based on a $90 \%$ quantile regression (Fig. 6). The response curves are paired. Each pair shows data from a period with high soil water content (left) and data from a dryer period thereafter (right). In order to demonstrate the degree of stomatal acclimation the response curve from the left dataset is also shown in the right one as grey line. The graphs showed that stomatal sensitivity changed drastically within a few days when soil moisture varied. Stomatal conductance was highest in January (6a) and March (6c). The short period of drought during February (6b) slightly increased sensitivity to VPD, whereas during April (6d) the drought led to much-reduced canopy conductance over the whole range of VPD. After a large rainfall event in May (6e), plants reverted the regulation pattern again but did not reveal as high conductance as in January or March, indicating the onset of the senescence of the leaves that may be speeded up by the April drought period. Nevertheless, the following dry period during May (6f) reduced stomatal conductance again while the senescence of the plants went on. Consequently, a rainfall event during late June did not reverse the performance any more $(6 \mathrm{~g})$ and the during the dry season (August), canopy conductance was reduced to a minimum (6h). 


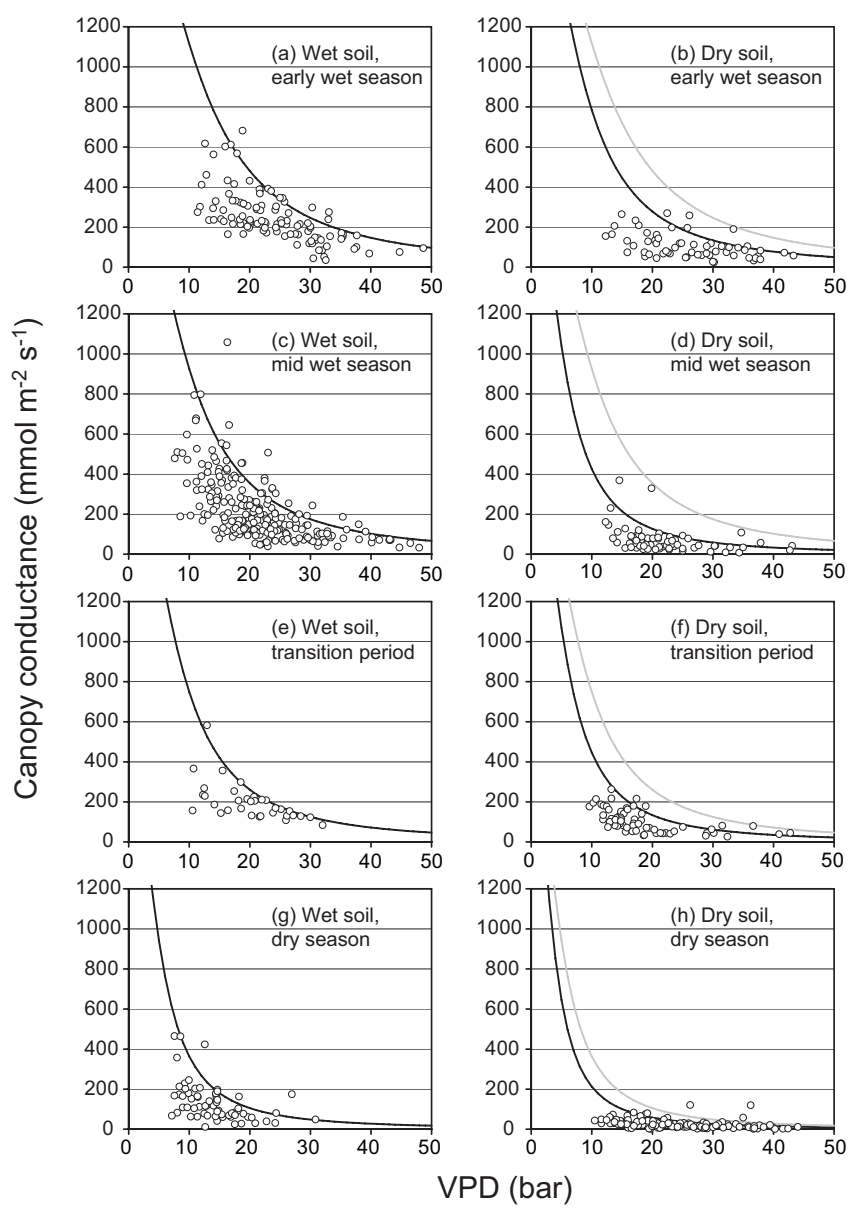

Fig. 6. VPD-response curves of stomatal conductance for the 8 periods as defined in Table 1. Data measured at saturating light conditions with incoming shortwave radiation being higher than $700 \mathrm{~W} \mathrm{~m}^{-2}$. The grey curves in the situations with dry soil (right graphs) symbolize the curves from corresponding situations with wet soils (left graphs).

Light saturated canopy photosynthesis was limited strongly by canopy conductance below a threshold of $250 \mathrm{mmol} \mathrm{m}^{-2} \mathrm{~s}^{-1}$ during all of the periods under consideration (Fig. 7a-h). During the periods with low soil moisture (right figures) canopy conductance did almost never exceeded this threshold and $\mathrm{CO}_{2}$ uptake by the canopy was almost constantly reduced. In addition, the few data sets with a canopy conductance around $250 \mathrm{mmol} \mathrm{m}^{-2} \mathrm{~s}^{-1}$ suggest a decrease of the photosynthetic capacity, which means that photosynthetic capacity was strongly coupled to stomatal sensitivity.

The seasonal trends of all important parameters are summarized in Fig. 8a-c. The coefficient $c$ (Eq. 10) is an indicator for the sensitivity of surface conductance to VPD, $F_{P \text {, sat }}$ for the photosynthetic capacity. $R_{\mathrm{av}}$ is the average nighttime respiration for each period and $R_{15}$ the normalized respiration rate at $15^{\circ} \mathrm{C}$ and optimum water conditions.

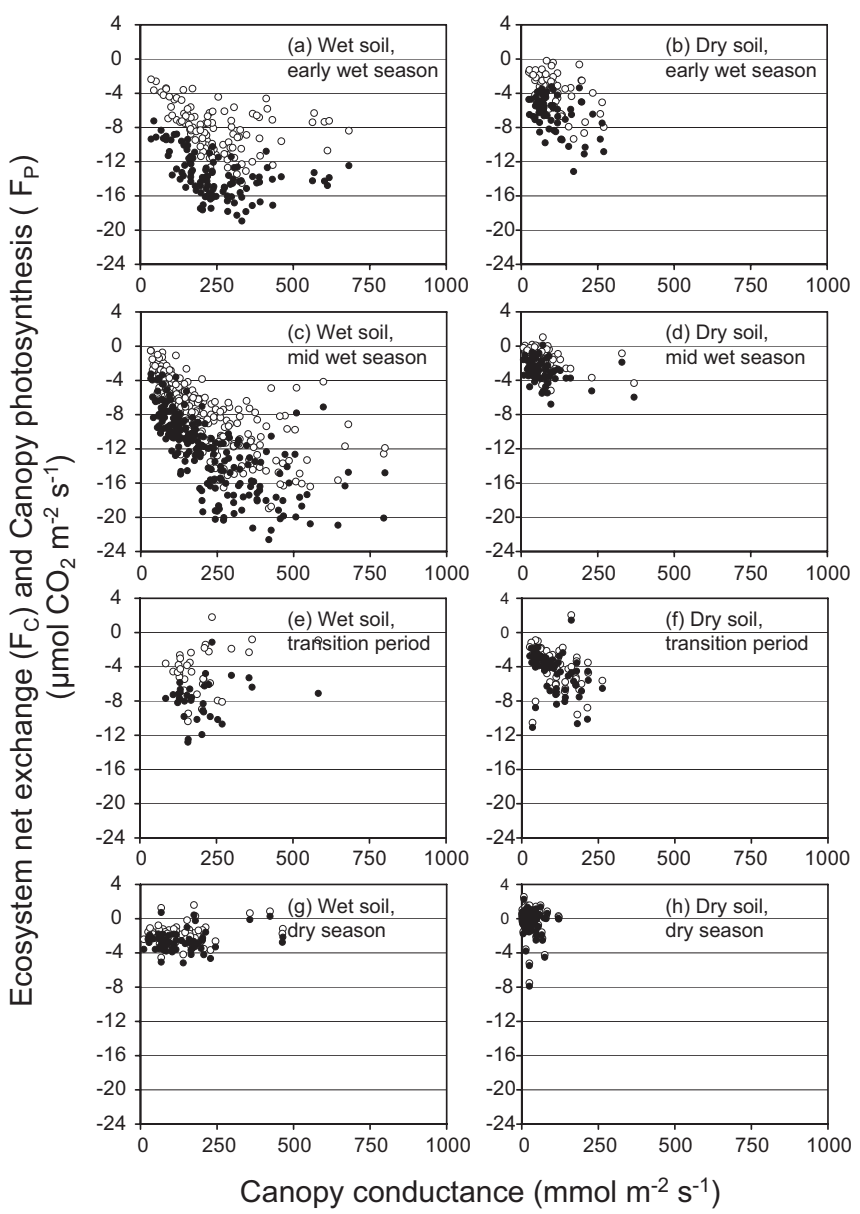

Fig. 7. Conductance response curve of $\mathrm{CO}_{2}$-fluxes for the 8 periods as defined in Table 1. Black dots symbolize the canopy gross photosynthetic flux, open circles the net ecosystem flux; data measured at saturating light conditions with incoming shortwave radiation being higher than $700 \mathrm{~W} \mathrm{~m}^{-2}$.

Each of these parameters showed a seasonal trend (dashed grey line) that was overlaid by mid-term responses to the respective drought periods, but the specific characteristics were different.

The seasonal trend of the coefficient $c$ revealed a broad minimum from January to March and constantly increased during the transition period towards the dry season. $C$ also revealed mid-term responses to the drought periods: during water stress, $c$ was increased and showed the more conservative regulation of the stomata.

The seasonal trend of $F_{P \text {,sat }}$ was an increase until March and a decrease thereafter - a typical performance for a plant canopy during the course of the growing season. This trend was overlaid by a reduction during drought.

Night time respiration seemed to be highest at the onset of the growing season, was stable on a slightly lower level during the main part of the growing season and decreased thereafter. This trend was overlaid by depressions 


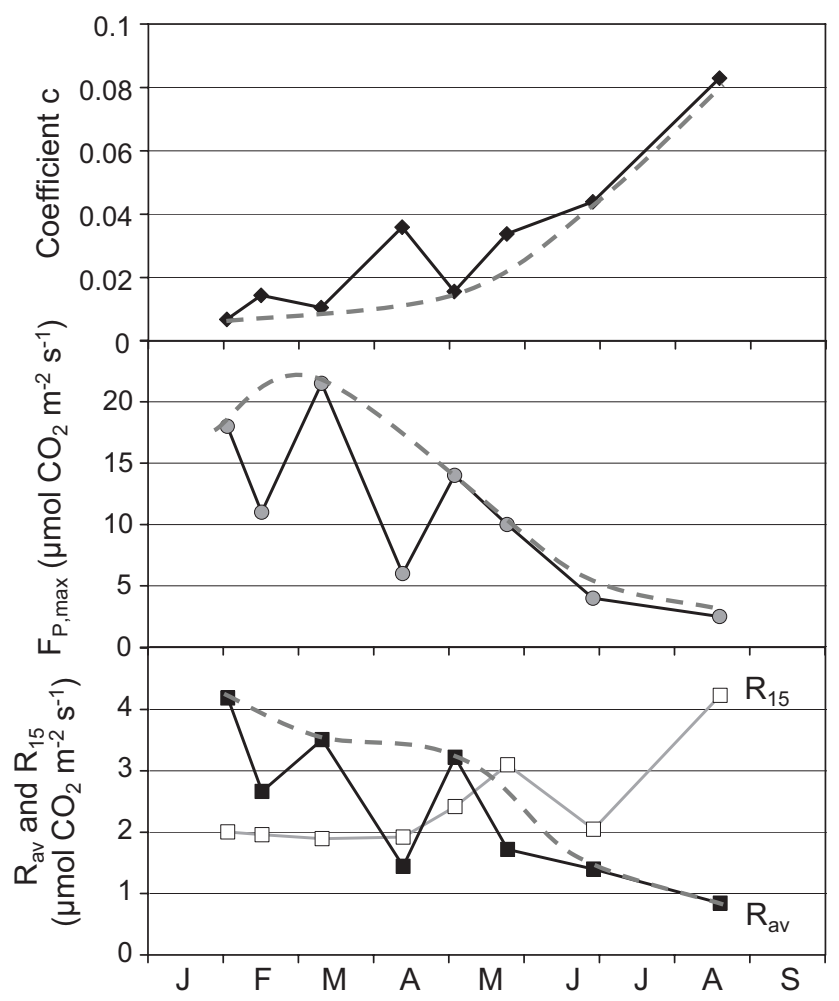

Fig. 8. Annual courses of the coefficient $c$ describing stomatal response sensitivity to VPD, of maximum canopy photosynthesis ( $\left.F_{P \text {, sat }}\right)$ average nighttime respiration $\left(R_{\mathrm{av}}\right)$ and $R_{15}$ as derived from the model. Each point represents the center of a period defined in Table 1. The dashed line shows a hypothetical seasonal course without intermediate drought periods.

during the drought periods, in particular in April. The initially high respiration rate is typical for seasonal ecosystems facing drought or frost periods (Arneth et al., 2006; Schimel and Mikan, 2005).

Figure 9 summarizes the close relationship between stomatal regulation and photosynthetic capacity by the close relationship between canopy photosynthetic capacity and surface conductance (Fig. 9a) and, in addition, a strong correlation between coefficient $c$ and canopy photosynthetic capacity (Fig. 9b) for the 8 periods under consideration.

\section{Discussion}

The convergence of the two savanna types in terms of flux properties may be the most surprising result of this study. Sectoral analysis of flux data has been conducted successfully in other studies, where distinct differences in fluxes between sectors could be related to differences in properties such as species composition or LAI of the canopy (Kutsch et al., 2005). At this site the fluxes were identical in spite of different soil properties and plant species composition as described by Scholes et al. (2001).
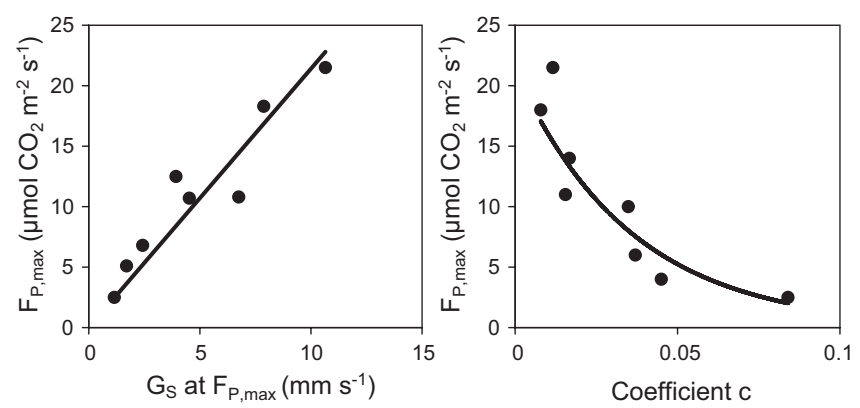

Fig. 9. Relations between photosynthetic capacity $\left(F_{P, \text { sat }}\right)$ and canopy conductance at $F_{P}$, sat (a) and between $F_{P \text {, sat }}$ and the coefficient $c$ describing stomatal response sensitivity to VPD (b) for the 8 periods under consideration.

This might be a sampling issue, because the area is very patchy (Archibald and Scholes, 2007). However, the two savanna types extend over at least $1 \mathrm{~km}$ in the respective footprint area. We suspect that the reasons for the functional convergence of the savanna sub-types could only be found by detailed studies on leaf-level eco-physiology. Kutsch (unpublished data) could show a spatial correlation between soil properties and eco-physiological strategies of the grass species. It was found that different species optimize their fluxes by balancing stomatal conductance and photosynthetic capacity between water availability (lower in the Acaciasite soils) and nutrient availability (higher in the Acacia-site soils). The resulting convergence allows to treat the data as one dataset in the following principle analysis of watercarbon interactions of fluxes in an African savanna ecosystem.

Respiratory patterns showed a strong dependency on temperature and soil moisture. In addition higher rates during the early stages of the wet season and a decrease thereafter even in periods of high soil moisture was detected. Seasonal changes in ecosystem respiration rates due to changes in biomass and activity were hard to detect because soil temperatures differed between the phenological stages. In addition, changes in activity correlate with changes in temperature and rainfall patterns and are "masked" by the temperature and soil moisture response curves (Kutsch et al., 2001b). The relatively high $Q_{10}$-value for wet conditions $(\sim 2.5)$ indicates a hidden seasonal change in activity. This was confirmed by comparing mean night time fluxes throughout the year: highest respiration rates were found at the onset of the wet season in January and February, followed by constant decrease thereafter that was overlaid by a less severe influence of water shortage during the growing period (Fig. 8c).

It is assumed that this is due to the growth respiration of the new biomass and the mineralization of easily decomposable organic matter that has been accumulated during the dry season. Augustine and McNaughton (2005) showed recently that the new growing plant biomass at the onset of the 
growing season is also favoured by a large inorganic nitrogen pool that has accumulated during the dry season, during which mineralization does not completely cease. Xu et al. (2004) found a similar pattern oak/grass savanna ecosystem in California. They also observed a "respiratory flush" after a rainfall event, as did Levine et al. (1996) at Pretoriuskop (30 km south of the Skukuza site) and Scholes et al. (1997) in savannas at Nylsvley, South Africa.

Maximum canopy-scale carbon dioxide fluxes at light saturation $\left(F_{C \text {, sat }}:-17 \mu \mathrm{mol} \mathrm{CO}_{2} \mathrm{~m}^{-2} \mathrm{~s}^{-1}\right)$ and canopy-scale photosynthetic capacity $\left(F_{P, \text { sat }}:-22 \mu \mathrm{mol} \mathrm{CO}_{2} \mathrm{~m}^{-2} \mathrm{~s}^{-1}\right)$ reported in this study are comparable with other eddycovariance studies of African savanna ecosystems, particularly when bearing in mind that the 2002/2003 growing season at Skukuza was characterised by an extremely low precipitation. Scanlon and Albertson (2004) measured fluxes from four savanna ecosystems along a precipitation transect across the Kalahari sands. They report values of $F_{P \text {,sat }}$ between -15 and $-20 \mu \mathrm{mol} \mathrm{CO}_{2} \mathrm{~m}^{-2} \mathrm{~s}^{-1}$ for the "drier end" of the transect (mean annual rainfall 365 and $407 \mathrm{~mm}$ ). A similar range is also reported in Williams and Albertson (2004) for a mixed Acacia-Combretum savanna in Botswana receiving a mean annual rainfall of $400 \mathrm{~mm}$, and by Veenendaal et al. (2004) for a Mopani-woodland in Botswana with $464 \mathrm{~mm}$ mean annual precipitation.

Scanlon and Albertson (2004), who collected only shortterm data of a few days during the 2000 wet season, interpreted differences in the light response curves of $F_{C}$ and the VPD response curve of water use efficiency between the sites as a long-term adaptation of the different vegetation types to the mean precipitation at each location. In our study we found a highly dynamic ecosystem response to environmental factors that may also be part of this adaptation. Our approach of defining different periods according to rainfall characteristics and soil moisture provided valuable qualitative insights.

In particular, it showed that the response of canopy conductance to VPD followed the soil moisture conditions very dynamically and that conductance and photosynthetic capacity were strongly coupled. Three findings are noteworthy:

1. The short-term regulation of canopy conductance was modified by a general seasonal trend and some mid-term acclimation to soil water conditions. This can be seen in the variation of the coefficient $c$ in Figs. 8 and 9.

2. The most constant parameter was water use efficiency (data not shown) that was influenced by VPD during the day but the VPD response curve of water usage did change only slightly during the course of the growing season and decreased by about $30 \%$ during the transition from wet to dry season.

3. The regulation of canopy conductance and photosynthetic capacity were closely related, suggesting a complex regulation pattern (Fig. 9).
Kutsch et al. (2001a) showed by means of model calculations that stomatal acclimation allows the plant to optimize for high carbon gain during periods of sufficient water supply and to save water during drought. It is important to note that decreases in stomatal conductance in many plants are inter-related with decreases in photosynthetic capacity (Hall and Schulze, 1980; Schulze and Hall, 1982). Whereas those authors assumed an un-coordinated response of stomatal conductance and photosynthetic capacity to soil water stress (Schulze and Hall, 1982), Flexas et al. (2006a, b) showed recently on the molecular level that stomatal closure triggers down-regulation of Rubisco either directly through its effects on chloroplast $\mathrm{CO}_{2}$ concentration or mediated by some common signalling (e.g. a response to abscisic acid). Data from this study were obtained by eddy covariance at the ecosystem scale and show the same pattern of inter-relation between stomatal conductance and photosynthetic capacity as leaf-level studies.

It is important to note that the decrease in stomatal conductance goes together with the down-regulation of photosynthetic capacity. As a consequence, $\mathrm{Ci} / \mathrm{Ca}$ may remain relatively stable and the isotopic fractionation will not be affected by drought as severely as expected. Therefore, predicted values of isotopic fractionation from large scale modeling may be wrong. The correlation between canopy photosynthetic capacity and maximum surface conductance seems to be relevant for scaling processes from leaf to ecosystem level and even to higher scales (e.g. Lloyd et al., 2008).

However, it is important to stress that theories developed for individual plants or leaves cannot be scaled simply to the vegetation level because different water use strategies and life cycles may compete for the available water and in this situation a conservative strategy may simply lead to a higher water usage by the competing neighbour (Schulze et al., 2005). Moreover, different plant functional types have different traits and life cycles that may influence the ecosystem properties much more than leaf scale acclimation. Decreases in the $f_{\mathrm{APAR}}$ from remote sensing as shown in Fig. 2a may indicate that the LAI is reduced during the dry periods. However, this observation has to be interpreted very carefully, because the correlation between $f_{\mathrm{APAR}}$ and LAI is scattering (Huemmrich et al., 2005) and influenced by changing optical properties of leaves during drought stress. Therefore, further studies including detailed process analyses and multispecies canopy modelling are highly required to explain the adaptive inter-relation of canopy conductance and photosynthetic capacity which is only poorly represented in higherscale models.

\section{Conclusion}

The eddy covariance measurements at a flux tower close to Skukuza in the Kruger National Park, South Africa, revealed the strong influence of water relations on the carbon fluxes 
in savanna ecosystems. While Merbold et al. (2008) showed the close relationship between canopy conductance and $F p_{\text {sat }}$ being constant over space, this study gave useful insights into the temporal dynamics of acclimation to changing conditions. The mid-term ecophysiological response to climate and/or soil moisture, respectively, is an important observation which is not included in any of the common models.

Acknowledgements. Eddy covariance measurements in the Kruger Park were supported by the US National Aeronautics and Space Administration (NASA, Grant NAG5-8705 and TE/03-000-0008 to NPH), the National Science Foundation (EAR-0120630 to NPH), NOAA (Grant NA17RJ1228 to NPH), by the South African National Research Foundation (RJS) and Center for Scientific and Industrial Research (RJS). WLK was funded by the German Science Foundation (DFG, DFG Ku 1099/2-1) and the European Commission (FP6, Project "CarboAfrica", Nr. 037132 and strongly supported by the Christian-Albrechts-University, Kiel. Construction of the micrometeorological tower near Skukuza was made possible through NASA funding to Jeff Privette for participation in EOS Validation and SAFARI-2000. The scientific collaboration of Mary Scholes, Harold Annegarn, Lackson Marufu, Pierre Ngok and numerous SAFARI-2000 personnel is gratefully acknowledged. The researchers and staff of Scientific Services in the Kruger National Park provided scientific, technical and logistical support. Finally, the authors wish to thank the game-guards of the Kruger National Park who kept us save during field work.

Edited by: E. Falge

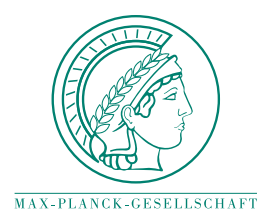

This Open Access Publication is financed by the Max Planck Society.

\section{References}

Archibald, S. and Scholes, R. J.: Leaf green-up in a semi-arid African savanna - separating tree and grass responses to environmental cues, J. Veg. Sci., 18, 583-594, 2007.

Archibald, S., Kirton, A., van der Merwe, M., Scholes, R. J., Williams, C. A., and Hanan, N.: Drivers of interannual variability in Net Ecosystem Exchange in a semi-arid savanna ecosystem, South Africa, Biogeosciences Discuss., 5, 3221-3266, 2008 ,

http://www.biogeosciences-discuss.net/5/3221/2008/.

Arneth, A., Veenendaal, E. M., Best, C., Timmermans, W., Kolle, O., Montagnani, L., and Shibistova, O.: Water use strategies and ecosystem-atmosphere exchange of $\mathrm{CO}_{2}$ in two highly seasonal environments, Biogeosciences, 3, 421-437, 2006, http://www.biogeosciences.net/3/421/2006/.

Aubinet, M., Grelle, A., Ibrom, A., Rannik, Ü., Moncrieff, J., Foken, T., Kowalski, A., Martin, P., Berbigier, P., Bernhofer, C., Clement, R., Elbers, J., Granier, A., Grünwald, T., Morgenstern, K., Pilegaard, K., Rebmann, C., Snijders, W., Valentini, R., and Vesala, T.: Estimates of the annual net carbon and water ex- change of forests: The euroflux methodology, Adv. Ecol. Res., 30, 113-175, 2000.

Augustine, D. J. and McNaughton, S. J.: Temporal asynchrony in soil nutrient dynamics and plant production in a semiarid ecosystem, Ecosystems, 7, 829-840, 2005.

Baldocchi, D. D., Xu, L. K., and Kiang, N.: How plant functionaltype, weather, seasonal drought, and soil physical properties alter water and energy fluxes of an oak-grass savanna and an annual grassland, Agr. Forest Meteorol., 123, 13-39, 2004.

Ball, J. T., Woodrow, I. E., and Berry, J. A.: A model predicting stomatal conductance and its contribution to the control of photosynthesis under different environmental conditions, in: Progress in photosynthesis research, edited by: Biggens, J., Martinus Nijhoff, Dordrecht, Holland, 221-225, 1987.

Beerling, D. J. and Osborne, C. P.: The origin of the savanna biome, Glob. Change Biol., 12, 2023-2031, 2006.

Beringer, J., Hutley, L. B., Tapper, N. J., Coutts, A., Kerley, A., and O'Grady, A. P.: Fire impacts on surface heat, moisture and carbon fluxes from a tropical savanna in northern australia, Int. J. Wildland Fire, 12, 333-340, 2003.

Cade, B. S. and Noon, B. R.: A gentle introduction to quantile regression for ecologists, Front. Ecol. Environ., 1, 412-420, 2003.

Chen, X. Y., Eamus, D., and Hutley, L. B.: Seasonal patterns of soil carbon dioxide efflux from a wet-dry tropical savanna of northern australia, Aust. J. Bot., 50, 43-51, 2002.

Chen, X. Y., Hutley, L. B., and Eamus, D.: Carbon balance of a tropical savanna of northern australia, Oecologia, 137, 405-416, 2003.

da Rocha, H. R., Frieatas, H. C., and Rosolem, R.: Measurements of $\mathrm{CO}_{2}$ exchange over a woodland savanna (Cerrado sensu stricto) in southeast Brasil, Biota Neotropica, 2, 1-10, 2002.

Flexas, J., Bota, J., Galmes, J., Medrano, H., and Ribas-Carbo, M.: Keeping a positive carbon balance under adverse conditions: Responses of photosynthesis and respiration to water stress, Physiol. Plant., 127, 343-352, 2006 a.

Flexas, J., Ribas-Carbo, M., Bota, J., Galmes, J., Henkle, M., Martinez-Canellas, S., and Medrano, H.: Decreased Rubisco activity during water stress is not induced by decreased relative water content but related to conditions of low stomatal conductance and chloroplast $\mathrm{CO}_{2}$ concentration, New Phytol., 172, 73-82, 2006b.

Hall, A. E. and Schulze, E. D.: Stomatal response to environment and a possible interrelation between stomatal effects on transpiration and $\mathrm{CO}_{2}$ assimilation, Plant Cell Environ., 3, 467-474, 1980.

Halldin, S., Saugier, B., and Pontailler, J. Y.: Evapotranspiration of a deciduous forest: Simulation using routine meteorological data, J. Hydrol., 75, 323-341, 1984.

Hanan, N. P., Kabat, P., Dolman, A. J., and Elbers, J. A.: Photosynthesis and carbon balance of a sahelian fallow savanna, Global Change Biol., 4, 523-538, 1998.

Herbst, M., Kutsch, W. L., Hummelshoj, P., Jensen, N. O., and Kappen, L.: Canopy physiology: Interpreting the variations in eddy fluxes of water vapour and carbon dioxide observed over a beech forest, Basic Appl. Ecol., 3, 157-169, 2002.

Huemmrich, K. F., Privette, J. L., Mukelabai, M., Myneni, R. B., and Knyazikhin Y.: Time-series validation of MODIS land biophysical products in a Kalahari woodland, Africa, Int. J. Remote Sens., 26, 4381-4398, 2005. 
Hutley, L. B., O'Grady, A. P., and Eamus, D.: Evapotranspiration from eucalypt open-forest savanna of northern Australia, Funct. Ecol., 14, 183-194, 2000.

Hutley, L. B., O'Grady, A. P., and Eamus, D.: Monsoonal influences on evapotranspiration of savanna vegetation of northern Australia, Oecologia, 126, 434-443, 2001.

Hutley, L. B., Leuning, R., Beringer, J., and Cleugh, H. A.: The utility of the eddy covariance techniques as a tool in carbon accounting: Tropical savanna as a case study, Aust. J. Bot., 53, 663-675, 2005.

Jensen, N. O. and Hummelshøj, P.: Derivation of canopy resistance for water vapour fluxes over a spruce forest, using a new technique for the viscous sublayer resistance, Agr. Forest Meteorol., 73, 339-352, 1995.

Kutsch, W. L., Herbst, M., Vanselow, R., Hummelshoj, P., Jensen, N. O., and Kappen, L.: Stomatal acclimation influences water and carbon fluxes of a beech canopy in northern Germany, Basic Appl. Ecol., 2, 265-281, 2001a.

Kutsch, W. L., Staack, A., Wötzel, J., Middelhoff, U., and Kappen, L.: Field measurements of root respiration and total soil respiration in an alder forest, New Phytol., 150, 157-168, $2001 \mathrm{~b}$.

Kutsch, W. L., Liu, C. J., Hörmann, G., and Herbst, M.: Spatial heterogeneity of ecosystem carbon fluxes in a broadleaved forest in northern germany, Global Change Biol., 11, 70-88, 2005.

Levine, J. S., Winstead, E. L., Parsons, D. A. B., Scholes, M. C., Scholes, R. J., Cofer, W. R., Cahoon, D. R., and Sebacher, D. I.: Biogenic soil emissions of nitric oxide (NO) and nitrous oxide $\left(\mathrm{N}_{2} \mathrm{O}\right)$ from savannas in South Africa - the impact of wetting and burning, J. Geophys. Res.-Atmos., 101, 23 689-23 697, 1996.

Levy, P.: Carbon dioxide exchange of Sahelian vegetation, University of Edinburgh, 1995.

Lloyd, C. R., Bessemoulin, P., Cropley, F. D., Culf, A. D., Dolman, A. J., Elbers, J., Heusinkveld, B., Moncrieff, J. B., Monteny, B., and Verhoef, A.: A comparison of surface fluxes at the HAPEXSAHEL fallow bush sites, J. Hydrol., 188-189, 400-425, 1997.

Lloyd, J., Bird, M. I., Vellen, L., Miranda, A. C., Veenendaal, E. M., Djagbletey, G., Miranda, H. S., Cook, G., and Farquhar, G. D.: Contributions of woody and herbaceous vegetation to tropical savanna ecosystem productivity: A quasi-global estimate, Tree Physiol., 28, 451-468, 2008.

Meinzer, F. C., Goldstein, G., Franco, A. C., Bustamante, M., Igler, E., Jackson, P., Caldas, L., and Rundel, P. W.: Atmospheric and hydraulic limitations on transpiration in Brazilian Cerrado species, Funct. Ecol., 13, 273-282, 1999.

Merbold, L., Ardö, J., Arneth, A., Scholes, R. J., Nouvellon, Y., de Grandcourt, A., Archibald, S., Bonnefond, J. M., Boulain, N., Bruemmer, C., Brueggemann, N., Cappelaere, B., Ceschia, E., El-Khidir, H. A. M., El-Tahir, B. A., Falk, U., Lloyd, J., Kergoat, L., Le Dantec, V., Mougin, E., Muchinda, M., Mukelabai, M. M., Ramier, D., Roupsard, O., Timouk, F., Veenendaal, E. M., and Kutsch, W. L.: Precipitation as driver of carbon fluxes in 11 African ecosystems, Biogeosciences Discuss., 5, 4071-4105, 2008 ,

http://www.biogeosciences-discuss.net/5/4071/2008/.

Meir, P., Grace, J., Lloyd, J., and Miranda, A. C.: Soil respiration in a rain forest in Amazonia and in Cerrado in central Brazil, in: Amazonian deforestation and climate, edited by: Gash, J. H. C., Nobre, C. A., Roberts, J. M., and Victoria, J. L., John Wiley and Sons, Chichester, 319-329, 1996.
Miranda, A. C., Miranda, H. S., Lloyd, J., Grace, J., Francey, R. J., McIntyre, J. A., Meir, P., Riggan, P., Lockwood, R., and Brass, J.: Fluxes of carbon, water and energy over Brazilian Cerrado an analysis using eddy covariance and stable isotopes, Plant Cell Environ., 20, 315-328, 1997.

Moncrieff, J. B., Massheder, J. M., de Bruin, H., Elbers, J., Friborg, T., Heusinkveld, B., Kabat, P., Scott, S., Soegaard, H., and Verhoef, A.: A system to measure surface fluxes of momentum, sensible heat, water vapour and carbon dioxide, J. Hydrol., 188189, 589-611, 1997.

Otter, L. B., Scholes, R. J., Dowty, P., Privette, J., Caylor, K., Ringrose, S., Mukelabai, M., Frost, P., Hanan, N., Totolo, O., and Veenendaal, E. M.: The southern African regional science initiative (SAFARI 2000): Wet season campaigns, S. Afr. J. Sci., 98, 131-137, 2002.

Reichstein, M., Tenhunen, J. D., Roupsard, O., Ourcival, J. M., Rambal, S., Miglietta, F., Peressotti, A., Pecchiari, M., Tirone, G., and Valentini, R.: Severe drought effects on ecosystem $\mathrm{CO}_{2}$ and $\mathrm{H}_{2} \mathrm{O}$ fluxes at three mediterranean sites: Revision of current hypothesis?, Global Change Biol., 8, 999-1017, 2002.

Sankaran, M., Ratnam, J., and Hanan, N. P.: Tree-grass coexistence in savannas revisited - insights from an examination of assumptions and mechanisms invoked in existing models, Ecol. Lett., 7, 480-490, 2004.

Sankaran, M., Hanan, N. P., Scholes, R. J., Ratnam, J., Cade, B. S., Ardo, J., Augustine, D. J., Banyikwa, F., Bronn, A., Bucini, G., Caylor, K., Coughenour, M. B., Diouf, A., Ekaya, W., Feral, C., February, E. C., Frost, P., Gignoux, J., Hiernaux, P., Higgins, S., Hrabar, H., LeRoux, X., Ludwig, F., Metzger, K., Prins, H. H. T., Ringrose, S., Sea, W., Tews, J., Worden, J., and Zambatis, N.: Determinants of woody cover in African savannas, Nature, 438, 846-849, 2005.

Santos, A. J. B., Silva, G., Miranda, H. S., Miranda, A. C., and Lloyd, J.: Effects of fire on surface carbon, energy and water vapour fluxes over campo sujo savanna in central Brazil, Funct. Ecol., 17, 711-719, 2003.

Scanlon, T. M. and Albertson, J. D.: Canopy scale measurements of $\mathrm{CO}_{2}$ and water vapor exchange along a precipitation gradient in southern Africa, Global Change Biol., 10, 329-341, 2004.

Schimel, J. P. and Mikan, C.: Changing microbial substrate use in arctic tundra soils through a freeze-thaw cycle, Soil Biol. Biochem., 37, 1411-1418, 2005.

Scholes, M. C., Martin, R., Scholes, R. J., Parsons, D., and Winstead, E.: $\mathrm{NO}$ and $\mathrm{N}_{2} \mathrm{O}$ emissions following the first simulated rains of the season, Nutr. Cycl. Agroecosys., 48, 115-122, 1997.

Scholes, R. J. and Walker, B. H.: An African savanna - synthesis of the Nylsvley study, Cambridge University Press, Cambridge, 306 pp., 1993.

Scholes, R. J. and Archer, S. R.: Tree-grass interactions in savannas, Annu. Rev. Ecol. Syst., 28, 517-544, 1997.

Scholes, R. J., Gureja, N., Giannecchinni, M., Dovie, D., Wilson, B., Davidson, N., Piggott, K., McLoughlin, C., Velde, K. v. d., Freeman, A., Bradley, S., Smart, R., and Ndala, S.: The environment and vegetation of the flux measurement site near Skukuza, Kruger National Park, Koedoe, 44, 73-83, 2001.

Schulze, E.-D., Beck, E., and Müller-Hohenstein, K.: Plant ecology, Springer, Berlin, 702 pp., 2005.

Schulze, E. D. and Hall, A. E.: Stomatal responses, water loss and $\mathrm{CO}_{2}$ assimilation rates of plants in contrasting environments, in: 
Encyclopedia of plant physiology, Physiological plant ecology, Ii. Water relations and carbon assimilation, edited by: Lange, $\mathrm{O}$. L., Nobel, P. S., Osmond, C. B., and Ziegler, H., Springer-Verlag, Berlin, Germany, 180-230, 1982.

Schulze, E. D., Kelliher, F. M., Körner, C., Lloyd, J., and Leuning, R.: Relationships among maximum stomatal conductance, ecosystem surface conductance, carbon assimilation rate, and plant nitrogen nutrition - a global ecology scaling exercise, Annu. Rev. Ecol. Syst., 25, 629-656, 1994.

Shugart, H. H., Macko, S. A., Lesolle, P., Szuba, T. A., Mukelabai, M. M., Dowty, P., and Swap, R. J.: The SAFARI 2000 - Kalahari transect wet season campaign of year 2000 , Global Change Biol., 10, 273-280, 2004.

Veenendaal, E. M., Kolle, O., and Lloyd, J.: Seasonal variation in energy fluxes and carbon dioxide exchange for a broadleaved semi-arid savanna (mopane woodland) in southern Africa, Global Change Biol., 10, 318-328, 2004.

Verhoef, A., Allen, S. J., De Bruin, H. A. R., Jacobs, C. M. J., and Heusinkveld, B. G.: Fluxes of carbon dioxide and water vapour from a Sahelian savanna, Agr. Forest Meteorol., 80, 231-248, 1996. von Stamm, S.: Linked stomata and photosynthesis model for Corylus avellana (hazel), Ecol. Model., 75/76, 345-357, 1994.

Walter, H.: Grasland, Savanne und Busch der ariden Teile Afrikas in ihrer ökologischen Bedingtheit, Jahrbuch der Wissenschaftlichen Botanik, 87, 750-860, 1939.

Walter, H.: Ecology of tropical and subtropical vegetation, Oliver and Boyd, Edinburgh, 1971

White, F.: The vegetation of Africa, Natural Resources Research, UNESCO, Paris, 356 pp., 1980.

Williams, C. A. and Albertson, J. D.: Soil moisture controls on canopy-scale water and carbon fluxes in an African savanna, Water Resour. Res., 40, W09302, doi:10.1029/2004WR003208, 2004.

Williams, C. A. and Albertson, J. D.: Contrasting short- and long-timescale effects of vegetation dynamics on water and carbon fluxes in water-limited ecosystems, Water Resour. Res., 41, W06005, doi:10.1029/2004WR003750, 2005.

Xu, L. K., Baldocchi, D. D., and Tang, J. W.: How soil moisture, rain pulses, and growth alter the response of ecosystem respiration to temperature, Global Biogeochem. Cy., 18, GB4002, doi:10.1029/2004GB002281, 2004. 